\title{
HUBUNGAN FAKTOR PERILAKU DAN LINGKUNGAN DENGAN KEJADIAN LUAR BIASA SUSPEK CHIKUNGUNYA DI DESA JASRI, WILAYAH KERJA PUSKESMAS KARANGASEM I, KABUPATEN KARANGASEM TAHUN 2017
}

\author{
Artikel Penelitian \\ David Budi Lukito', Soraya Juventia Primadanti', Rania Ayu Permata P.K. ${ }^{1}$, \\ Wayan Citra Wulan Sucipta Putri ${ }^{2}$ \\ ${ }^{1}$ Program Studi Pendidikan Dokter, Fakultas Kedokteran, Universitas Udayana \\ ${ }^{2}$ Departemen Ilmu Kesehatan dan Kedokteran Pencegahan, Fakultas Kedokteran Universitas \\ Udayana \\ Email : suciptaputri@unud.ac.id
}

\begin{abstract}
ABSTRAK
Latarbelakang. Chikungunya merupakan salahsatu penyakit infeksi dengan gejala demam, nyeri sendi, dan ruam yang disebabkan oleh virus chikungunya (CHIKV) dan ditularkan melalui gigitan nyamuk. Pada tahun 2017, terjadi kejadian luarbiasa (KLB) dengan 61 kasus suspek chikungunya di Desa Jasri Kabupaten Karangasem.

Tujuan. Untuk mengidentifikasi faktor yang berhubungan dengan KLB chikungunya Desa Jasri Kabupaten Karangasem pada tahun 2017.

Metode. Rancangan analitik dengan desain kasus control menggunakan data primer dari hasil wawancara dan observasi. Sampel kasus dikumpulkan dengan criteria kasus adalah yang tercatat sebagai chikungunya didalam catatan medic dan bertempat tinggal di Desa Jasri dan sampel control dikumpulkan dengan kriteria yang bertempat tinggal di sekitar penderita. Sampel berjumlah 38 kasus dan 38 kontrol menggunakan teknik purposive consecutive sampling.

Hasil. Hasil penelitian menunjukkan variabel yang berhubungan secara statistic bermakna dengan kejadian chikungunya adalah variable anggota keluarga yang menderita chikungunya (OR 23.619, $\mathrm{p}=0.000)$, pencahayaan rumah (OR 4.3, $\mathrm{p}=0.009)$, keadaan TPA alamiah(OR 3.9, $\mathrm{p}=0.024)$ dan status tidak bekerja sebagai factor protektif(OR 0.3, $\mathrm{p}=0.000)$.

Simpulan. Kepada Puskesmas Karangasem I agar mempertahankan upaya promotif dan preventif tentang Pemberantasan Sarang Nyamuk (PSN), meningkatkan pencatatan dan pemantauan penderita chikungunya, dan kepada masyarakat untuk terus membudayakan PSN, menjaga kebiasaan 3M plus, meningkatkan penerangan rumah dan lingkungan sekitar rumah.
\end{abstract}

Kata kunci: chikungunya, kejadian luarbiasa, perilaku, lingkungan

\begin{abstract}
Background. Chikungunya is aninfectious disease indicated by some symptomssuch as fever, joint pain, and skinrash caused by chikungunya virus (CHIKV) and transmitted through themosquitobites. In 2017, anoutbreak of chikungunya with 61 cases had happened in Jasri Village, Karangasem district..
\end{abstract}

Objective. To identify some factors that associated to chikungunya out break in Jasri Village, Karangasem district in 2017.

Methods. An analytic study with case control design was conducted using primary data from the interview and observation. Case's samples were patient suspected with chikungunya in medical record and while control's samples were those who live around the caset's bome. 38 cases and 38 controls obtained using purposive consecutive sampling method.

Results. Variabels that associated statistically significant with the incidence of chikungunya out break include bistory of family member infected by chikungunya (OR 23.619, $p=0.000$ ), house brightness (OR 4.3, $p=0.009$ ), natural water container condition (OR 3.9, $p=0.024$ ) and unemployed (OR 0.3, $p=0.000$ ) whichmean as a protective factor.

Conclusion. To Karangasem Health Center to maintain the good progress of promotive and preventive care of mosquitonesteradication, improve the irregistry record and surveillance of chikungunya patient, and for theresident of Karangasem I to keep their habit of $3 M$ plus behavior, eradicating mosquitonest, and improve their house and surrounding ligbting.

Keywords : chik.ungunya, outbreak, behavior, environment 


\section{PENDAHULUAN}

Chikungunya adalah penyakit infeksi yang disebabkan oleh virus Chikungunya (CHIKV) yang ditularkan melalui gigitan nyamuk (arthropod borne virus/mosquito-borne virus). Penularannya di Asia berada dalam siklus transmisi manusia-nyamukmanusia dengan vektor yang paling umum adalah Aedesaegypti dan Aedesal bopictus. Gejala klinis yang sering muncul dan menjadi criteria klinis yaitu demam mendadak > 38,50 C, nyeri persendian hebat (severe arthralgia), dan atau dapat disertai ruam (rash). Meski tidak mematikan, namun chikungunya mampu melumpuhkan sementara penderitanya hingga mengganggu aktivitas seharihari. Penyakit yang bersifat menular ini mudah menyebar di kalangan masyarakat Indonesia yang tempat tinggalnya belum memenuhi syarat kesehatan.(Kementrian Kesehatan Republik Indonesia; 2012. World Health Organization; 2009)

Kejadian Luar Biasa (KLB) chikungunya di Indonesia pertama kali dilaporkan pada tahun 1973 di Samarinda Provinsi Kalimantan Timur dan di Jakarta. Pada tahun 2010, 20 provinsi, termasuk Provinsi Bali, melaporkan 53.899 kasus chikungunya. Menurut laporan kasus chikungunya di Bali oleh Departemen Kesehatan terdapat sebanyak 103 kasus pada tahun 2009 dan 246 kasus pada tahun 2010. (World Health Organization; 2009. Yoshikawa MJ, 2013)

Pada Puskesmas Karangasem I, didapatkan data bahwa sejak awal hingga tahun 2016 terdapat nolkasus chikungunya, namun dari Januari hingga Juli 2017 didapatkan 61 kasus suspek chikungunya dan seluruhnya didapatkan disatu desa yakni Desa Jasri, Kelurahan Subagan, Kecamatan dan Kabupaten Karangasem. Menurut laporan Pemberantasan Sarang Nyamuk (PSN) setempat, Angka Bebas Jentik (ABJ) di desa tersebut belum mencapai target 95\% dengan ABJ padaJuli 2017 sebesar 92,4\% dan pada Agustus 2017 menjadi 89,5\%.(Dinas Kesehatan Amlapura; 2017) Hal ini berpotensi untuk terus mengalami perburukan hingga akhir tahun.

Adanya peningkatan kasus suspek chikungunya disertai dengan penurunan $A B J$ menyebabkan perlunya upaya mengidentifikasi factor risiko dari penyakit ini. Identifikasi faktorrisiko chikungunya di wilayah kerja Puskesmas Karangasem I penting untuk dilakukan karena potensi dampak yang luas dari penyakit ini di masyarakat. Besarnya kejadian sakit chikungunya dan tingginya tingkat penularan dapat berdampak pada aspek social ekonomi akibat potensi hilangnya penghasilan dari penderita selama menderita sakit yang juga akan berlanjut kemasalah yang lebih kompleks seperti malnutrisi. Identifikasi factor risiko chikungunya juga akan membantu petugas kesehatan dalam perumusan strategi pencegahan dan intervensi yang efektif, efisien, dan tepat sasaran sehingga akan mendukung masyarakat dan pemerintah dalam mempercepat pembangunan kesehatan di wilayah kerja Puskesmas Karangasem I.

\section{METODE PENELITIAN}

Penelitian ini merupakan penelitian analitik dengan desain kasus kontrol (casecontrol). Penelitian dilakukan pada tanggal 13 September 2017 sampai 30 September 2017. Populasi target dari penelitian ini adalah orang dengan suspekchikungunya di daerah Karangasem, Bali. Kriteria kasus yang diinklusi sebagai sampel pasien suspekchikungunya yang tercatat dalam rekam medis di Puskesmas Karangasem I dan bertempat tinggal di Desa Jasri, Kelurahan Subagan, Kecamatan dan Kabupaten Karangasem selama periode tahun 2017 tanpa disertai penyetaraan karakteristik terlebih dahulu. Kriteria kontrol yang diinklusi adalah subyek yang bertempat tinggal di wilayah sekitar tempat tinggal kasus. Sampel diambil menggunakan teknik purposivekonsekutive sampling, yaitu dengan mengambil sampel berdasar kelompok kasus dan kontrol secara berurutan hingga jumlah sampel terpenuhi sesuai dengan kriteria inklusi dan ekslusi yang sudah ditetapkan selama periode penelitian. Data yang digunakan adalah data primer yang diperoleh dari hasil observasi dan wawancara terstruktur. Jumlah sampel minimal dihitung berdasarkan rumus Lemeshow untuk unmatching case control dimana didapatkan jumlah kasus minimal adalah 38. Penelitian ini menggunakan perbandingan kasus dan control 1:1 sehingga total sampel adalah 76. Untuk mengukur faktor-faktor yang berhubungan dengan kejadian chikungunya digunakan lembar ekstraksi data, lembar observasi dan kuisioner. Data kemudian dianalisa secara univariat dan bivariate. 


\section{HASIL PENELITIAN}

Telah dilakukan pengumpulan data terhadap 76 responden dari dua banjar yang mengalami peningkatan kasus dan dinyatakan KLB chikungunyaoleh Dinas Kesehatan Kabupaten Karangasem dan Provinsi Bali dengan responden kasus sebanyak 38 orang dan responden kontrol sebanyak 38 orang. Responden kasus dan kontrol sebagian besar berjenis kelamin perempuan berturutturut sebanyak 22 orang $(57,9 \%)$ dan 23 orang (60,5\%). Kelompok usia 24-44 tahun merupakan proporsi terbanyak untuk responden kasus maupun kontrol 16 orang $(42,1 \%)$ dibandingkan dengan kelompok usia lainnya dengan usia termuda adalah 8 tahun dan usia tertua adalah 73 tahun. Sebagian besar kedua kelompok responden di Desa Jasri Kabupaten Karangasem memiliki riwayat lulusan SD 8 orang $(21,1 \%)$. Berdasarkan jenis pekerjaan, kelompok kasus sebagian besar bekerja sebagai buruh 12 orang $(31,6 \%)$, sedangkan responden kontrol sebagian besar bekerja sebagai ibu rumah tangga12 orang $(31,6 \%)$.

Sebagian besar responden kasus mengeluhkan nyeri sendi, demam, ruam, serta gejala lainnya meliputi sakit kepala, gatal, kesemutan, dan lemas sebanyak 19 orang (25\%). Lama sakit sebagian besar responden kasus kurang dari satu minggu 19 orang(25\%). Hanya sebagian kecil responden kasus yang sebelum sakit sempat menginap di rumah yang terdapat penderita chikungunya 9 orang (23,7\%). Sebagian besar responden kasus memiliki anggota keluarga dalam satu rumah yang juga mengalami keluhan yang sama 31 orang $(81,6 \%)$. Hampir seluruh responden kasus berobat saat sakit, dengan sebagian besar mencari pengobatan ke dokter praktek swasta 22 orang $(28,9 \%)$.

Hasil analisa bivariatterhadap karakteristik sosiodemografis menunjukkan bahwa responden dengan status tidak bekerja memiliki probabilitas untuk terinfeksi chikungunya 0.367 kali dibanding yang bekerja. Status tidak bekerja ini berpengaruh secara signifikan terhadap kejadian chikungunya sebagai faktor protektif $(\mathrm{OR}=0,367, \mathrm{p}=0,036)$. Hasil analisa bivariate terhadap faktor perilaku dan lingkungan menunjukkan bahwa variabel-variabel yang berpengaruh secara bermakna ( $p$ value $<0,05)$ terhadap kejadian KLB chikungunya antara lain: adanya riwayat anggota keluarga yang menderita chikungunya $(\mathrm{OR}=23,619 ; \mathrm{p}=0,000)$, kondisitempat penampungan air (TPA) yang berisiko $(\mathrm{OR}=3,923$; $\mathrm{p}=0,024)$, dan kurangnyapencahayaan rumah $(\mathrm{OR}=4,304 ; \mathrm{p}=0,009)$. Faktor - faktor risiko lainnya seperti kebiasaan menguras TPA, menutup TPA, mengubur barang bekas, menggunakan abate, menggantung pakaian pada dinding, menggunakan kelambu, keadaan TPA dan non TPA berdasarkan observasi, diperoleh $\mathrm{p}$ value $>0,05$ sehingga dapat disimpulkan bahwa kedelapan variabel ini tidak bermakna secara statistik.

Tabel 1. Hasil Analisa Bivariat Karakteristik Responden dengan Kejadian Suspek Chikungunya di Desa Jasri Kabupaten Karangasem tahun 2017

\section{Kasus (n=38) Kontrol (n=38) OR (95\% CI;p value)}

\begin{tabular}{|c|c|c|c|}
\hline \multicolumn{4}{|c|}{ JenisKelamin (n (\%)) } \\
\hline Laki-laki & $16(51,6)$ & $15(48,4)$ & \multirow{2}{*}{$\begin{array}{l}\text { 1,115(0,446-2,785; } \\
0,815)\end{array}$} \\
\hline Perempuan & $22(48,8)$ & $23(51,2)$ & \\
\hline \multicolumn{4}{|c|}{ KelompokU sia (n (\%)) } \\
\hline$<24$ tahun & $6(75)$ & $2(25)$ & \multirow{2}{*}{$-3,375(0,636-17,922 ; 0,135)$} \\
\hline$=24$ tahun & $32(47)$ & $36(53)$ & \\
\hline \multicolumn{4}{|c|}{ Pendidikan (n (\%)) } \\
\hline Rendah & $31(50,8)$ & $30(49,2)$ & \multirow{2}{*}{$\begin{array}{l}1,181(0,381-3,662 ; \\
0,773)\end{array}$} \\
\hline Tinggi & $7(46,6)$ & $8(53,4)$ & \\
\hline
\end{tabular}




\begin{tabular}{llll}
\hline Pekerjaan (n (\%)) & & & \\
\cline { 1 - 3 } Iburumahtangga, pelajar, dantidakbekerja & $11(28,9)$ & $20(52,6)$ & $0,367(0,142-0,945 ;$ \\
\cline { 1 - 3 } Bekerja & $27(71,1)$ & $18(47,4)$ & $0,036)$ \\
\hline
\end{tabular}

\section{RiwayatAnggotaKeluarga yang Menderita Chikungunya (n (\%))}

\begin{tabular}{llll}
\hline Ada & $31(35,4)$ & $6(64,6)$ & 23,619 \\
\hline
\end{tabular}

\section{DISKUSI}

Analisis menunjukkan adanya hubungan antara riwayat anggota keluarga responden yang menderita chikungunya dengan kejadian chikungunya dan terbukti sebagai faktor resiko terjadinya kejadian chikungunya, dimana hasil ini kemungkinan besar disebabkan nyamuk sebagai vektor yang memiliki radius terbang maksimal 500 meter, dimana sebagian besar responden memiliki tempat tinggal yang sama atau berdekatan dengan anggota keluarga maupun tetangga yang memiliki riwayat chikungunya. ${ }^{5}$ Analisis data juga menunjukkan bahwa responden yang memilikikeadaan TPA alamiah berisiko mempunyai risiko 3,923 kali lebih besar

Tabel 2. Hasil Analisa BivariatFaktor Perilaku dan Lingkungan dengan Kejadian Suspek Chikungunya di

Desa Jasri Kabupaten Karangasem tahun 2017

\begin{tabular}{|c|c|c|c|}
\hline & $\begin{array}{l}\text { Kasus } \\
(n=38)\end{array}$ & Kontrol $(n=38)$ & OR $(95 \% \mathrm{CI} ; \mathrm{p}$ value $)$ \\
\hline \multicolumn{4}{|c|}{ Kebiasaan Menguras TPA(n (\%)) } \\
\hline Buruk & $7(43,8)$ & $9(56,2)$ & \multirow{2}{*}{$\begin{array}{l}0,728 \\
(0,240-2,208 \\
0.574)\end{array}$} \\
\hline Baik & $31(51,6)$ & $29(48,4)$ & \\
\hline \multicolumn{4}{|c|}{ Kebiasaan Menutup TPA (n (\%)) } \\
\hline Tidak & $26(47,3)$ & $29(52,7)$ & \multirow{2}{*}{$\begin{array}{l}0,672 \\
(0,244-1,853 \\
0.442)\end{array}$} \\
\hline Ya & $12(57,1)$ & $9(42,9)$ & \\
\hline \multicolumn{4}{|c|}{ Kebiasaan Mengubur Barang Bekas (n (\%)) } \\
\hline Buruk & $31(49,2)$ & $32(50,8)$ & \multirow{2}{*}{$\begin{array}{l}0,830 \\
(0,251-2,749 ; \\
0761)\end{array}$} \\
\hline Baik & $7(53,8)$ & $6(46,2)$ & \\
\hline \multicolumn{4}{|c|}{ Kebiasaan Menggunakan Abate (n (\%)) } \\
\hline Buruk & $18(50,0)$ & $18(50,0)$ & \multirow{2}{*}{$\begin{array}{l}1,000 \\
(0,406-2,461 \\
1 \cap n \cap)\end{array}$} \\
\hline Baik & $20(50,0)$ & $20(50,0)$ & \\
\hline
\end{tabular}

Kebiasaan Menggantung Pakaian pada Dinding (n (\%))

\begin{tabular}{llll}
\hline $\mathrm{Ya}$ & $17(80,9)$ & $21(19,1)$ & 0,655 \\
\hline
\end{tabular}




\begin{tabular}{llll}
\hline \multicolumn{4}{l}{ Kebiasaan Menggu nakan Kelambu (n (\%)) } \\
\hline Tidak & $36(49,3)$ & $37(50,7)$ & 0,486 \\
& & $(0,42-5,603 ;$ \\
Ya & $2(66,7)$ & $1(33,3)$ & $0,556)$ \\
\hline
\end{tabular}

$\begin{aligned} & \text { Keadaan TPA Alamiah Berdasarkan Observasi } \\
& \text { (n (\%)) }\end{aligned}$
\begin{tabular}{llll} 
Berisiko & $34(56,7)$ & $26(43,3)$ & $\begin{array}{l}3,923 \\
(1,134-13,576 ; \\
0.024)\end{array}$ \\
\hline Tidak Berisiko & $4(25)$ & $12(75)$ & \\
\hline
\end{tabular}

\section{Pencahayaan (n (\%))}

\begin{tabular}{llll}
\hline Kurang & $23(41,1)$ & $33(58,9)$ & 4,304 \\
\hline
\end{tabular}

Menderita chikungunya daripada responden yang tidak memiliki keadaan TPA alamiah berisiko. Hasil yang didapat kemungkinan besar disebabkan karena sebagian besar responden kurang menyadari adanya tempat-tempat yang terbentuk secara alamiah berpotensi dapat menampung air sehingga dapat menjadi tempat perkembangbiakan vektor pembawa penyakit chikungunya (Wuryanto MA. 2009). Selain itu, analisa juga menemukan hubungan bermakna antara pencahayaan rumah dengan kejadian chikungunya. Hasil ini sejalan dengan penelitian Pratamawati D.A. \& Anggraeni Y.M., yang menyatakan ada hubungan antara pencahayaan dengan kejadian suspek chikungunya di Dusun Sinoman dan Dusun Rekesan Kecamatan Sidorejo Lor. (Pratamawati DA, 2014). Hasil ini kemungkinan besar disebabkan karena nyamuk cenderung berada pada ruangan yang memiliki pencahayaan kurang dari 60 lux dibanding pencahayaan yang lebih dari 60 lux. Untuk hubungan pekerjaan dengan kejadian suspekchikungunya, analisis hasil menunjukkan bahwa faktor ini memiliki hubungan serta terbukti berpengaruh, akan tetapi bukan sebagai faktor risiko namun sebagai faktor protektif. Hal ini kemungkinan besar disebabkan oleh lingkungan kerja yang berbeda, sehingga memungkinkan responden yang memiliki pekerjaan lain untuk tertular di daerah atau lingkungan tempat kerjanya, sedangkan Ibu Rumah Tangga, Pelajar, dan yang tidak bekerja lebih cenderung banyak menghabiskan waktu di rumah, sehingga risiko untuk tertular di lingkungan luar rumah lebih kecil (Oktikasari FY, 2006).

Kemudian, hubungan kebiasaan menguras, menutup, dan mengubur juga tidak menunjukkan bukti maupun hubungan dengan kejadian chikungunya, hasil ini kemungkinan disebabkan juga oleh kebiasaan masyarakat yang tidak menampung air dan secara rutin menjual barang-barang bekas mereka, sehingga tidak menimbulkan tumpukan atau genangan yang dapat menjadi sarang nyamuk. Selanjutnya, faktor kebiasaan menggunakan abate juga tidak jauh berbeda dengan kebiasaan lain, dimana hasil analisis yang tidak menunjukkan adanya hubungan dan tidak terbukti sebagai faktor risiko yang kemungkinan disebabkan oleh karena adanya penyuluhan dan pembagian abate oleh dinas kesehatan setempat ke masyarakat Desa Jasri setelah terjadinya KLB suspekchikungunya, sehingga sebagian besar responden menggunakan abate saat penelitian ini dilakukan, walaupun masih ada beberapa responden yang belum menggunakan abate dengan rutin. Yang terakhir, kebiasaan menggantung pakaian pada dinding dan menggunakan kelambu dengan kejadian suspekchikungunya juga tidak menunjukkan hubungan yang bermakna serta tidak terbukti meningkatkan faktor risiko. Kemungkinan besar disebabkan karena data yang diperoleh didapatkan dari hasil wawancara sehingga responden dapat menyampaikan jawaban yang tidak sesuai dengan kondisi sebenarnya serta tidak dilakukan observasi 
sehingga memungkinkan terjadinya bias. Selain itu untuk kebiasaan menggunakan kelambu dapat disebabkan karena periode aktivitas nyamuk yang cenderung lebih aktif pada pagi hingga sore hari dimana kelambu tidak digunakan.

Terdapat beberapa kelemahan dalam penelitian ini. Tidak semua faktor yang berhubungan dengan kejadian chikungunya diteliti, sehingga memungkinkan bahwa faktor-faktor yang diteliti tidak memiliki hubungan atau terdapat hubungan namun tidak bermakna secara statistik maupun klinik, misalnya faktor budaya, genetik, status nutrisi, daya tahan tubuh, dan lain-lain.Pada proses wawancara, kurang ditekankan dan juga tidak ditanyakan secara pasti tentang periode dilakukannya kebiasaan sehingga dapat terjadi perbedaan pengertian dan periode antar sampel (recall bias). Terdapat beberapa faktor pengganggu atau faktor konfounding yang tidak diteliti dan dianalisis pada penlitian ini, sehingga memungkinkan hasil beberapa variabel yang didapatkan menjadi bias.Adanya intervensi dari petugas kesehatan terhadap lingkungan tempat penelitian sebelum penelitian dimulai juga berkontribusi terhadap kelemahan penelitian.

\section{SIMPULAN}

Penelitian ini menemukan hubungan yang bermakna dan terbukti sebagai factor risiko terhadap kejadian KLB chikungunya di desa Jasri, Kabupaten Karangasem 2017 yaktiadanya riwayat anggota keluarga yang menderita chikungunya, keadaan TPA alamiah yang lebih berisiko berdasarkan observasi, dan pencahayaan rumah yang kurang. Penelitian ini juga menemukan factor tidak bekerja sebagai factor protektif. Dari temuan ini, Puskesmas Karang asem I khususnya diharapkan untuk mempertahankan upaya promotif dan preventif tentang Pemberantasan Sarang Nyamuk (PSN) kepada masyarakat wilayah kerja Puskesmas Karangasem I, meningkatkan system pencatatan dan pemantauan suspek chikungunya agar dapat dilakukan tindakan pencegahan penularan, serta ditambahkan subprogram chikungunya pada kelompok program pencegahan penyakit menular. Masyarakat diharapkan membudayakan kegiatan PSN di dalam rumah dan lingkungan sekitarnya dengan tujuan memutus rantai penularan chikungunya. Masyarakat dapat tetap melakukan kebiasaan menguras TPA minimal seminggu sekali, menutup TPA secara rutin, mengubur barang bekas, menghindari kebiasaan menggantung pakaian didinding, dan membiasakan memakai abate dan kelambu, meningkatkan penerangan yang ada di dalam rumah maupun lingkungan rumah.

\section{DAFTAR PUSTAKA}

Pedoman Pengendalian Demam Chikungunya Edisi 2: Kementrian Kesehatan Republik Indonesia; 2012.

Guidelines for prevention \& control of Chikungunya Fever: World Health Organization; 2009.

Yoshikawa MJ, Kusriastuti R. Surge of dengue virus infection and chikungunya Fever in bali in 2010: the burden of mosquito-borne infectious diseases in a tourist destination. Tropical medicine and health. 2013;41(2):6778.

Laporan Penyelidikan Epidemiologi Suspek Demam Chikungunya di Desa Jasri, Kelurahan Subagan, Kab. Karangasem Tanggal 12 Juli 2017. Dinas Kesehatan Amlapura; 2017.

Soegijanto S. DemamBerdarah Dengue Edisi-2: Airlangga University Press; 2006.

Wuryanto MA. Aspek sosial dan lingkungan pada kejadian luarbiasa (KLB) chikungunya (studikasus KLB Chikungunya di Kelurahan Bulusan Kecamatan Tembalang Kota Semarang). The Indonesian Journal of Health Promotion (Jurnal Promosi Kesehatan Indonesia). 2009;4(1):68-74.

Pratamawati DA, Anggraeni YM. Behavior and Environmental Risk Factor on Chikungunya Outbreaks at Salatiga City in 2012= Faktor Risiko Perilaku Dan Lingkungan Rumah Pada Kejadian Luar Biasa Chikungunya Di Kota SalatigaTahun 2012. Vektora: Jurnal Vektor dan Reservoir Penyakit. 2014;6(1 Jun):1-8.

Oktikasari FY, Susanna D, Djaja IM. Faktor Sosiodemografi dan Lingkungan yang Mempengaruhi Kejadian Luar Biasa Chikungunya di Kelurahan Cinere, Kecamatan Limo, Kota Depok 2006. Makara Kesehatan. 2008;12:20-36. 